\title{
Groundwater legislation and controls for sustainability: a case study in Niseko, Japan
}

\author{
S. Hori \\ Graduate School of Global Environmental Studies, \\ Kyoto University, Japan
}

\begin{abstract}
Groundwater is an important and indispensable natural water resource although enacting a groundwater law has been postponed for a long time. After World War II, the main water supply system in this country was changed to relying on river water instead of groundwater. The River Act was established in 1971, but the Groundwater Act did not undergo any substantial changes. Recently, there has been a new movement in society about legislation and controls of groundwater. Some land which is covered by green forest and which is a source ground water had been bought by both foreign and domestic investors. This event has received much attention from media all over the country, and people have a good chance to reconsider how we could keep a sustainable groundwater supply system for future generations. In these circumstances, legislation and controls of groundwater are hotly disputed issues in Japan. This paper analyses the uses of groundwater and the Japanese groundwater law through discussion of the case study of Niseko. The municipal government established in this area a new type of groundwater legislation in 2011. I suggest how people could seek sustainable groundwater controls by extending the municipality level to a national level, and looking for solutions after two years of operation.
\end{abstract}

Keywords: groundwater resource management, sustainability, legislation and controls, Niseko, groundwater conservation ordinance, water and society

\section{Introduction}

Groundwater is one of the important natural water resources in addition to surface water. Nevertheless, there is no central fundamental law for groundwater from the perspective of the conservation of sustainable groundwater in Japan. 
Recently, groundwater is facing new challenges. In the Forestry Agency of the Ministry of Agriculture, Forestry and Fisheries had published a press release on the $9^{\text {th }}$ December 2010 which confirmed transactions involving wasteland and green forest land with foreign investors in Japan. This snippet of information was successful in drawing the attention of society to the problem and people gradually realised that the development of sustainable solutions for groundwater are very important and indispensable. The basic principle for groundwater legislation had been disputed. Water laws were divided into many branches depending on their special characteristics. For example we have The Industrial Water Law, Building Water Law, Mining Act, Quarrying Law, Gravel Digging Law, Environmental Pollution Prevention Act, Environmental Basic Law and the Water Pollution Prevention Act, etc. Under these circumstances, each municipality has to take the initiative in groundwater conservation instead of the national government. The lack of a national law, local authorities have to make local laws.

From a view point of history, why was the passing of the Groundwater Law postponed? Before WWII, most of the people made a living from agriculture and water supply relied on both groundwater and surface water. There were a lot of border disputes between villages related to what is a fair distribution of water. It is obvious that there was a lack of national groundwater rules. After WWII, the main water supply system shifted to surface water from groundwater. After the River Act passed in 1971, there was a decrease in conflicts among private individuals. The majority no longer discussed the need of a groundwater policy. In the middle of 1970s the contamination of groundwater and land subsidence became social problems during the rapid economic growth. The government only enforced The Industrial Water Law, Building Water Law, and Environmental Pollution Prevention Act.

After the press released the news that some land, which is a source of groundwater, had been bought by both foreign and domestic investors society has gradually paid attention to how the groundwater resource could be preserved in a sustainable way for future generations. Niseko is a good example of a groundwater policy. The municipal government established a new type of groundwater legislation in 2011. There are many transactions involving wasteland and forest land. This paper analyses a case study of the Groundwater Conservation Ordinance in Niseko, Japan.

\section{Methodology}

This paper analyses the new approach and process for groundwater conservation in a case study of Niseko, Hokkaido. In a field study of Niseko in February 2012, we had interviews with local administrative officers, local inhabitants, farmers and workers. We also analyzed legal documents required in the implementation of the groundwater conservation management. We aim to develop solutions for sustainable groundwater legislation and controls. 


\section{Description of the study area}

\subsection{Niseko's geographic and climate settings}

Niseko is located in western Hokkaido, an island in northern Japan, surrounded by Mts. Yotei, Niseko-Annupuri and Mt. Konbudake. It is located approximately at latitude 42.52 degrees north, and at longitude 140.48 degrees east. The area is $197.13 \mathrm{~km}^{2}$. Mt. Yotei has an elevation of $1898 \mathrm{~m}$, Mt. Niseko-Annupuri 1308m and Mt. Konbudake $1045 \mathrm{~m}$. Niseko and its neighbouring areas of Otaru, Kutyan, and Rusutsu, are designated as national parks. They comprise a round the year tourist resort with beautiful natural settings. The national park occupies more than $13.5 \%$ of the land area of Niseko and $74 \%$ of natural forest. The Shiribetu river is the $6^{\text {th }}$ longest river in Hokkaido flows approximately in the centre of Niseko and joins the Magari river and the Konbu river. The highest average annual temperature is $21^{\circ} \mathrm{C}$ and the lowest is $-6.0^{\circ} \mathrm{C}$. In winter, the northwest monsoon brings moisture from the sea causing falls of snow when it hits the mountains. This is an area of heavy snowfall; the deepest snow accumulation of the year is 2 meters. The melted snow flows into the Shiribetsu River running through the town.

\subsection{Economic and demographic factors}

The main industries of Niseko are agriculture and tourism which is especially famous in the winter season. The population of Niseko is 4,669 and the number of households was 2,217 in May 2013. The primary agricultural products are potato, rice, melon, and asparagus. This area is known for its ski resorts. The number of tourists is about 1.40 million throughout the year and in 2007 the number of foreign tourists was 10 times larger than in 2001. Most of the visitors are from Asia and Oceania. After successful strategies for developing the tourism industries, which was beyond expectations, both foreign and domestic investors also found the value of Niseko from a different perspective.

\subsection{Water availability and demand}

In the areas with a heavy snowfall in the winter, melted snow flows into Shiribetu River which runs through the town. In the resort areas, the average consumption of piped water per person is larger than in other regions. It is an under regulated environment from the point of view of sustainable management of the groundwater The forest is considered as the source of drinking water. A groundwater policy is necessary to seek how to give a balance between sustainable conservation and the key industry. Individual water consumption per day in Ikoi village and Hot spring village, and the volume of water supplied are extremely high. How is the sustainable strategy in Niseko designed by regional authority? 
Table 1: Water consumption and population served by piped water, Niseko (2012).

\begin{tabular}{|l|c|c|c|c|}
\hline & $\begin{array}{c}\text { Water } \\
\text { consumption } \\
\text { in } 2012\left(\mathrm{~m}^{3}\right)\end{array}$ & $\begin{array}{c}\text { Population } \\
\text { served by piped } \\
\text { water }\end{array}$ & $\begin{array}{c}\text { Water } \\
\text { consumption per } \\
\text { person }\left(\mathrm{m}^{3}\right)\end{array}$ & $\begin{array}{c}\text { Individual water } \\
\text { consumption per } \\
\text { day (litres) }\end{array}$ \\
\hline Urban area & 355146 & 2788 & 127.4 & 340.0 \\
\hline Soga & 99329 & 513 & 193.6 & 530.5 \\
\hline Miyata & 21518 & 205 & 105.0 & 287.6 \\
\hline Kondou & 50084 & 299 & 167.5 & 458.9 \\
\hline Niseko & 129158 & 228 & 566.5 & 1552.0 \\
\hline Katura & 1894 & 21 & 90.2 & 247.1 \\
\hline hot spring village & 1878 & 2 & 939.0 & 2572.6 \\
\hline Ikoi village & 24534 & 5 & 4906.8 & 12443.3 \\
\hline Fukui & 21155 & 289 & 73.2 & 200.5 \\
\hline Total & 704696 & 4350 & 162.0 & 443.8 \\
\hline Source & & & \\
\hline
\end{tabular}

Source: Niseko town official website: http://www.town.niseko.lg.jp/

\section{Principles of the groundwater ordinance}

The development of sustainable water conservation has been discussed for a long time, ever since the Meiji era when the emperor was restored to power. Groundwater is always an important natural water resource as well as surface water. As explained above before, there is a discussion about a sustainable groundwater policy and its management. There is no fundamental groundwater law passed by the government, Groundwater Ordinances at a local level. Why are those municipal ordinances considered as the basic legislation for sustaining the regional environmental resource? It is because the River Act states that Groundwater is public property But on the other hand, the Civil Law states that Groundwater is private property. This private property implied This means that the laws did not match reality. To understand Groundwater regulations in Japan, the Common Law also covers its weakness of private property.

But time has gradually changed the views of society that groundwater may no longer be regarded as private property. For example, it is very difficult to divide liquid water under someone's land. A border between two houses is obviously visible. There may be a wall between them. When we think about the groundwater, how could we divide water from a huge water jar under the ground? In addition, it flows all the time within the water jar. Japanese people traditionally admit that groundwater is public property which is what common law states.

\subsection{Niseko's Groundwater Conservation Ordinances}

The town of Niseko gave a press release that the Groundwater Conservation Ordinance will come into force on September $1^{\text {st }}, 2011$ [1]. This was a strong initiative by municipal authority themselves to protect their own local drinking water [2]. The Town Hall specified a large area of land to be preserved in its 
natural state as public property. The ordinance calls for the efficient utilization and equitable access and sharing of the region's water resources to ensure a sustainable social, environmental and economic benefit for all. The key principles of Niseko's Groundwater Conservation Ordinance are summarized below:

This ordinance based on the principle of the Niseko Environmental Basic Ordinance. (Niseko Ordinance No. 29, 2001). The main intention is the control of water pollution and drought, and to authorize some natural conservation areas in and around the source of drinking water. Protecting the irreplaceable groundwater for the future will be great contribution the health and culture of the local people (Article 1).

The responsibility of the town council is to protect the sustainable social, environmental and economic benefits of groundwater, especially to protect citizens from hindrance on their, and to pursue a groundwater policy (Article 3). The responsibilities of water users are recharging groundwater, reducing water usages and cooperating with the local authority in the management and its policy of sustainable groundwater (Article 4).People who you cannot excavate water groundwater must have authorization from the headman of the town.

One cross section of pump's exhaust slot should be over $8 \mathrm{~cm}^{2}$. In addition, to change the arrangement and position of pipe strainer, otherwise to amplify an area of cross section also need to ask permission of the headman of the town. The headman may not grant permission to water users unless they satisfy the conditions of the licensing standards written in by Article 6. Before the government or other local public bodies agree to utilize the groundwater of Niseko, the head of the town must agree that it is permitted under Article 1. The town headman has the authority to add additional qualifications or conditions on water users if it is necessary (Article 5).

There are four main licensing standards in groundwater conservation. (1) It shall not impede an efficient water supply for citizens. (2) It shall not have a negative influence on existing system of the source and supply of water. (3) The use of the water should be necessary and consistent with sustainability. (4) It should agree that there is no alternative. (Article 6). The applicant must explain the plan of the installation work in a meeting for the local residents. This meeting should be announced in public 10 days beforehand and notified by letter to the town head. The registration applicant has to report the results of the meeting to the town headman without delay. When the matter is under discussion, the applicant must reach an agreement with local people (Article 7). A registration applicant shall submit an application to the town headman with the following information; the name of the authorized representative, the name of the company, the purpose for which groundwater will be used, the position of pipe strainer, the kind of pump, the cross section area of the exhaust slot, the average quantity of water to be pumped per day, the location of the well with a map, and other information which the town council may require (Article 8). After the town hall has accepted the application, town headman shall discuss it with the Niseko committee responsible for the source of groundwater (Article 9). The town headman should announce his decision within 60 days according to the 
provisions of Article 8 (Article 10). After completion of the well, a report must be submitted to the town council within 15 days who will conduct an inspection in the name of the town headman (Article 11).

People who obtain the permission, is under the obligation both to construct The well must include an instrument for measuring the amount water drawn per month this must be reported each month to the town headman. (Article 12). Person who inherit, borrow or amalgamate with their own well, a permitted well facility shall succeed to its status to a legal heir. They shall report the changes within 30 days to the town headman (Article 15).

The licence for the well shall be withdrawn if: (1) when the business is closed (2) when the water is NOT mechanically pumped, (3) when its area of cross section has been reduced to less than $8 \mathrm{~cm}^{2}$. When it lapses, it shall also be reported to the town headman (Article 16). The town headman shall rescind the licence granted to applicants who applied by deceitful or improper means. If a company uses groundwater without permission, the Town Council shall as a matter of urgency order a cut in the water intake after a warning has been given and ignored for the specified time. (Article 17).The town headman shall order the administrative officers to enter and inspect the facilities if that is necessary (Article 18).

The town headman shall advise or guide licensors or deputies and to recommend taking any necessary steps (Article 19).After the recommendation in Article 19, if licensors or deputies neglect their duties, the town headman is may order the implementation (Article 20). When licensors or deputies obey town headman's recommendation in Article 18 or orders in Article 19, it is necessary to report the town headman about an examination result from administrative officers (Article 21). If any person does not obey the order under Article 20, then the town headman shall order the abeyance of the licences (Article 22). Any person, who refuses the recommendation of Article 19, and the order of Article 20 without justifiable grounds, shall announce one's name in public (Article 23). Any person who refuses the orders given under the preceding paragraph of Article 17, 20, and 22 shall pay a fine not exceeding 500000 yen (approximately $1 €=130$ yen as of $3,825 €)$. Any person who neglects or forgets to notify the town manager within 15 days after the facilities are finished, shall pay fine not exceeding 300000 yen. Making a false declaration or refusing, disturbing or evading an on the spot investigation shall pay a fine not more than 300000 yen (Article 25). This ordinance shall also apply mutatis mutandis to any act in violation of the preceding articles to any representative of juridical person, deputy, employees, and other workers (Article 26).

\subsection{Conservation strategies and challenging in Niseko}

As the melted snow flows into Niseko town, the rich forests utilize recharged groundwater such as sump and subsoil water. People could not live without the benefits of nature and they have to use the limited water resources that we have carefully. How can people manage sustainable development in economic, social, and cultural? Groundwater policy delayed establishing the fundamental law that replaces the common law and other laws related to groundwater. The most 
notable regulative features of Niseko are the stating of penalties and the requirement to giving revealing one's full name in public are specified in the ordinance with legal sanctions. It states that groundwater is local common property. At the same time it sends a strong message to protect local environments by levying a fine on the violators of the rules. This is a new approach compared with other ordinances from different regions. Most of the environmental problems are the result of gathering tiny environmental changes day by day. Water policy must be also adapted to those environmental changes, no matter whether they are small or big. There is no doubt that regional administrative authorities know the current environmental circumstances in their own area. They have the capacity to make a prompt response to the urgent environmental problems. These new kinds of ordinance have covered the lack of fundamental groundwater laws at a local level. Although, the legal structure is not sufficient at present, Japan has legal treaties for water conservation. When we think about preserving local water, we need to be flexible in our approach. Water supply and demand should be in a one to one ratio. Lately there has been a press release of a report from both a voluntary member of the House of Representatives and the House of Councillors. They produced ideas for establishing a new fundamental groundwater Act. Japan needs a new national Groundwater law which can combine national and local laws to ensure sustainability in the management of groundwater.

We believe that children should inherit a sustainable system for managing groundwater. Policy makers and stakeholders must continue to find ways of preserving the water environment.

\section{Conclusions and recommendations}

After the Groundwater Conservation Ordinance of Niseko came into force in September 2011, groundwater conservation after the ordinance was followed. There were many obstacles in enforcing the regulation from the beginning. The Town Hall carried out surveys of land where the source of drinking-water, as groundwater is located. The town administrative office could not identify the contact information of some of the land owners from outside. Complicated social issues are connected with each other in water management. For example in the past a very little piece of worthless land was sold by unscrupulous real estate developers [3]. It is difficult to track the owners of land after inheritance. One of the key solutions is that a local administrative government must cooperate with the other local administrative bodies if it is to respond promptly to a problem [4]. In January 2013, when the author did the first field survey in Niseko, we found that there was one drinking water company that had avoided building a manufacturing plant in the preservation area. The reason was that many intricate examinations deter investors. Niseko passed pioneering legislation. The town headman showed a strong initiative in favour of sustainable water resource management. It is crucial to work with the general consensus of local people in considering regional water resources, but it also very important to have a strong leader to achieve it. Policy makers should see long term benefits of sustainable 
water management. It often takes priority over the short term benefits for the town. Small cities tend to rely on a corporation tax for a larger part of their income. To make a balance between conservation and local finance, the national government is able to include a budget for part of the cost for local water governance in regional water policy [5]. However, the regional authority should be allowed to make decisions about authorizing regional water controls. For next challenge for legislation and controls in Niseko, the ordinance should be studied in the context of the various cases year by year. Enacting legislation is only the starting point. The environment has not changed slowly. But once water is polluted, people will suffer badly for decades. This research should continue analyzing how the legislation works for a sustainable preservation of the environment in near future.

\section{References}

[1] Niseko, Groundwater Conservation Ordinance, http://www.town.niseko.lg. jp/machitsukuri/kankyo/cat265/post_35.html, accessed $10^{\text {th }}$ July 2013.

[2] Hokkaido prefecture, Ground Water Conservation Act, http://www.pref.hokkaido.lg.jp/ss/stt/mizusigen/mizusigen.htm, accessed $10^{\text {th }}$ July 2013.

[3] Naoki Kawakubo, "The responsibility of unlawful responsibility - the selling of waste land by unscrupulous real-estate developers." RETIO, Vol. 31, 1995.

[4] Fumito Mizutani, Takuya Urakami, "Identifying network density and scale economies for Japanese water supply organizations," Papers in Regional Science, Vol. 80, pp. 211-230, 2001.

[5] J.W. Milliman, "Water Law and Private Decision-Making: A Critique," Journal of Law and Economics, Vol. 2, pp. 41-63, 1959. 